\title{
The response of phytoplankton, zooplankton and macrozoobenthos communities to change in the water supply from surface to groundwater in aquaculture ponds
}

\author{
Zorka Dulić $^{1 *}$, Zoran Marković ${ }^{1}$, Miroslav Živić ${ }^{2}$, Miloš Ćirić ${ }^{3}$, Marko Stanković1, \\ Gordana Subakov-Simić ${ }^{2}$ and Ivana Živić \\ 1 Faculty of Agriculture, University of Belgrade, 11080 Belgrade, Serbia \\ ${ }^{2}$ Faculty of Biology, University of Belgrade, 11000 Belgrade, Serbia \\ 3 Institute for Chemistry, Technology and Metallurgy, University of Belgrade, 11000 Belgrade, Serbia
}

Received 26 October 2013; Accepted 20 January 2014

\begin{abstract}
Investigating forces driving the structure of aquatic communities has long been an important issue in ecology. In the present study, we focused on the effects of changed water supply for aquaculture ponds on phytoplankton, zooplankton and macrozoobenthos communities during two seasons of rearing common carp. We compared these communities between two types of inflow water: surface sources of water a reservoir pond, two open wells and a small stream and groundwater - deep tube well. Significant changes were observed in environmental variables after the introduction of the groundwater source: oxygen concentration and water hardness decreased, while conductivity, phosphorus and un-ionized ammonia increased. Results revealed that all investigated groups, except Mollusca (macrozoobenthos), decreased in species richness, abundance and biomass due to changed water chemistry, but differed in the level of susceptibility. Rotifera and Cladocera were the most affected showing a sharp decline in density and number of species since $66 \%$ of species disappeared from the ponds. The abundance of Copepoda was relatively high although significantly lower under new conditions, with adults being more tolerant to changed inflow water than nauplii larvae. Phytoplankton had the highest potential to replace previous species with newcomers more adapted to changed water chemistry, providing 36 immigrant species, whereas 49 became extinct. Although mainly influenced by fish predation, Chironomidae (macrozoobenthos) were undoubtedly affected by changed water chemistry. These results suggest profound changes in three key ecological groups produced by significant changes of important environmental variables and water quality after the shift from surface to groundwater supply.
\end{abstract}

Key words: Phytoplankton / zooplankton / macrozoobenthos / water quality / aquaculture ponds

\section{Introduction}

Ponds and shallow lakes are a specific type of aquatic ecosystems differing in many ways from large systems as lakes and reservoirs. Owing to different hydrological characteristics as low depth, these water bodies usually do not experience seasonal temperature-induced water column stratification and thus lack thermocline. These habitats are more under the influence of the weather and various anthropogenic factors in their immediate surroundings (Rettig et al., 2006). Compared to rivers and big lakes, ponds support higher biodiversity and often present a resort for rare species (e.g., have higher numbers of

\footnotetext{
*Corresponding author: zorkad@agrif.bg.ac.rs
}

macroinvertebrate species) (Wood et al., 2003; Williams et al., 2004). It has been confirmed that small artificial ponds, made for a variety of reasons, from ornamental and recreational to those of more economic value, as aquaculture or irrigation ponds, contribute a great deal to the regional freshwater biodiversity (Céréghino et al., 2008; Ruggiero et al., 2008). In fact, Williams et al. (1997) proposed creation of new ponds as potential sources for enhancement of local biodiversity particularly in impoverished environments.

Nevertheless, high biodiversity value of small inland water bodies is under constant threat from a variety of anthropogenic influences, namely eutrophication, secondary salinization and terrestrialization. On the other hand, man-made shallow lakes and ponds, can be very effective 
in simulating conditions existing in these small systems (Jeffries, 2002) thereby providing acceptable "playgrounds" for studying effects of the major anthropogenic stressors on a range of aquatic communities. Small manmade ponds used for fish production usually have a daily introduction of feed for cultured fish. Fish additionally feed on the natural food present in the ponds. As a result of fish predation on large cladocerans, small species of zooplankton dominate this community. High nutrient accumulation provided by added feed and fish excrements causes elevated phytoplankton production and Cyanobacteria prevalence later in the season (Pechar, 2000). This type of habitat is optimal for macrozoobentos species tolerant to high organic load as Chironomids and Oligochaeta; thus they usually dominate the bottom of fish ponds.

The aim of this study was to investigate the sensitivity of major ecological groups (phytoplankton, zooplankton and macrozoobenthos) in three small man-made ponds used for carp rearing to changes in water chemistry induced by altering water sources. These communities are significant indicators of ecological status of a range of water habitats and changes in abundance and diversity can be considered as a response to variations in water quality and might reflect modifications produced in freshwater food webs (Abrantes et al., 2009; Cho et al., 2011).

The new water supply coming from a deep tube well provided unique conditions to these small ponds that enabled us to assess a potentially threatening condition to the biodiversity of natural and artificial ponds. We hypothesize that after the introduction of groundwater supply the most significant environmental variables will be modified in the ponds, degrading the water quality and thus decreasing abundance and diversity of three aquatic communities, phytoplankton, zooplankton and macrozoobenthos.

\section{Materials and methods}

\section{Study site}

The experiment was carried out in three earthen fish ponds at the Centre for Fishery and Applied Hydrobiology of the Faculty of Agriculture, University of Belgrade from May to October in 2008 and 2009 (Fig. 1). The ponds are identical in size, next to each other and have an area of 0.09 ha (per pond). Before the start of every experimental year ponds were drained, aquatic weeds were removed. Further on, disking of the dried soil was applied and agricultural lime evenly distributed to the ponds. During the first year of the experiment, ponds were supplied with surface water from a reservoir pond, two open wells and a nearby small stream. During the second year, ponds were filled and maintained only with water from the 136-m deeptube well. Ponds were stocked with 400 carp yearlings per pond, with average weight of $105-115 \mathrm{~g}$ at the beginning of every investigation year. Fish were fed daily with pelleted feed at feeding rate of $2 \%$

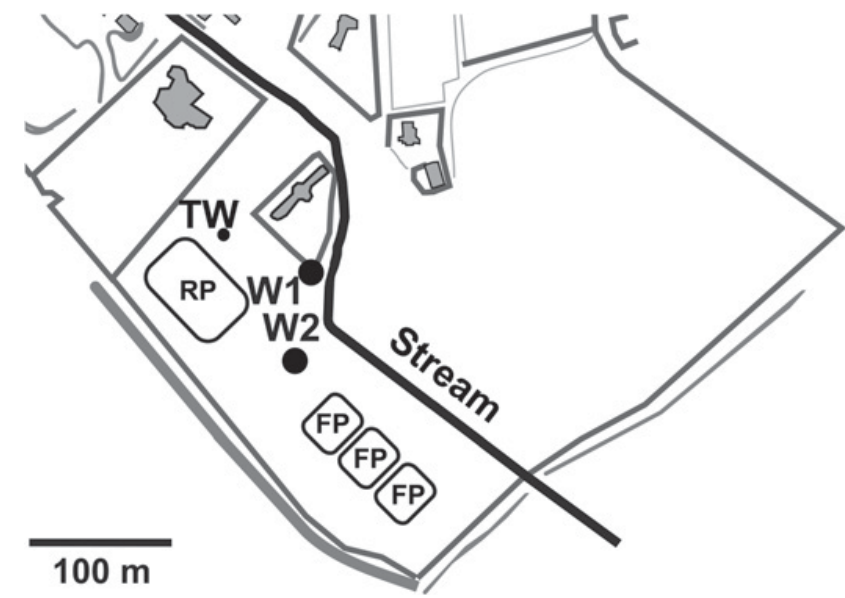

Fig. 1. Map of the study area showing the location of fish ponds and water supplies: FP, fish ponds; RP, reservoir pond; W1 and W2, open wells; TW, deep tube well.

of the total fish biomass. Fish biomass $\left(\mathrm{m}_{\mathrm{f}}\right)$ was measured at every sampling occasion as an average of 50 individuals.

\section{Sampling, in situ measurements and laboratory analysis}

Water samples were taken every 2 weeks from May to October in 2008 and 2009 from the ponds. Measurements of water temperature $(t), \mathrm{pH}$, dissolved oxygen (DO) and conductivity (EC) were recorded in situ using a water field kit, WTW MULTI 340i/SET and transparency with Secchi disc (SDT). The water samples for laboratory analysis of soluble reactive phosphorus (SRP), total ammonia nitrogen expressed as un-ionized ammonia (UIA) using table values (Alabaster and Lloyd, 1980), water hardness $\left({ }^{\circ} \mathrm{dH}\right)$, chemical oxygen demand as potassium permanganate oxidation (COD) and chlorophyll a (Chla) were collected every 2 weeks with a 1-L bottle from the centre of each pond and analysed according to APHA (1998).

In order to determine the cause of very high $\mathrm{EC}$ in the deep tube well water, concentration of additional ions $\left(\mathrm{Ca}^{2+}, \mathrm{Mg}^{2+}, \mathrm{Na}^{+}, \mathrm{K}^{+}, \mathrm{F}^{-}, \mathrm{Cl}^{-}\right.$and $\left.\mathrm{SO}_{4}^{2-}\right)$ were measured before the beginning of the second investigation year. Concentrations of calcium and magnesium were measured by titration with EDTA ( 311 and $318^{\circ} \mathrm{C}$, respectively). Sodium and potassium were determined by flame emission with an air-acetylene flame (Method 3111 B. Atomic Absorption Spectrometry/Direct Air-Acetylene Flame method). Water anions $\left(\mathrm{F}^{-}, \mathrm{Cl}^{-}\right.$and $\left.\mathrm{SO}_{4}^{2-}\right)$ were determined with an ion chromatograph (DIONEX 4000i) using the standard methods (EPA method 300.0: 1993).

Phytoplankton, zooplankton and macrozoobenthos were sampled bi-monthly from three sites (inflow, middle and outflow areas) of each fish pond (nine sites in total). Phytoplankton samples were collected with a transparent $1 \mathrm{~L}$ plastic tube and after filtration through a $22-\mu \mathrm{m}$ plankton net were transferred to a $100-\mathrm{mL}$ plastic bottle. 
The samples were fixed with $1 \%$ acidified Lugol's iodine solution. Transects were counted using inverted microscope Leica DMIL at $200 \times$ magnification. The linear dimensions of all species were measured with Carl Zeiss Primo Star microscope at $400 \times$ and $1000 \times$ magnification with examination of 25 randomly selected cells and trichoms for most abundant species (Smayda, 1978). Phytoplankton biovolume was calculated using proposed standard set of geometric models applied to the individual cells, coenobia, colonies or filaments (Hillebrand et al., 1999). Phytoplankton was identified using the standard taxonomic keys (Huber-Pestalozzi et al., 1983; Krammer and Lange-Bertalot, 1986, 1988; Komárek and Anagnostidis, 1998, 2005).

Zooplankton samples were collected from three sites in every pond by immersing a transparent plastic 1-L tube collecting $3 \mathrm{~L}$ per pond. Samples were filtered through a $75-\mu \mathrm{m}$ net and fixed with $4 \%$ formalin solution. Organisms were identified and counted in a SedgewickRafter cell using a compound microscope Carl Zeiss with maximum magnification of $160 \times$. Three $1 \mathrm{~mL}$ subsamples per pond were examined and their average taken. Density is given as the number of individuals per litre. Rotifera and Cladocera were identified to the species level using standard keys (Flosner, 1972; Koste, 1978), whereas Copepoda were grouped into adult and two larval stages, copepodites and nauplii. Estimation of biomass was done using tables of average values for different zooplankton species (Morduhai-Boltiviskoi, 1954) multiplied by the density of each species.

Macrozoobenthos was collected from three sites in every pond using Eckman dredge. Samples were washed through a $250-\mu \mathrm{m}$ mesh size sieve in order to remove mud. The organisms were placed in plastic bottles and fixed with $96 \%$ ethanol. The collected material was identified using Bresser stereomicroscope. Ephemeroptera, Diptera, Oligochaeta, Odonata and Mollusca were identified using standard taxonomic keys (Rozkošny, 1980; Vallenduuk and Moller Pillot, 2007; Moller Pillot, 2009). Since only Chironomidae and Mollusca were present in significant numbers during the investigation seasons, the rest of the identified groups were not mentioned in the results.

\section{Data analysis}

Multivariate analysis of variances (MANOVA) was used to compare environmental and biotic data between ponds using STATISTICA, version 5.0. MANOVA showed that there were no statistically significant differences between ponds concerning environmental and biotic data. Therefore, biotic data from the single sample date were pooled together by summing the abundances from all nine samples (three ponds $\times$ three sampling sites) and dividing them by the total sampling area: $9 \times 0.008755 \mathrm{~m}^{2}$ in the case of benthic macroinvertebrates, the total sampling volume for zooplankton $(9 \times 1 \mathrm{~L})$ and phytoplankton $(9 \times 1 \mathrm{~L})$.
Since ten physical and chemical variables and fish biomass were analysed during the course of the investigation, in order to summarize their effects on zooplankton, phytoplankton and macrozoobenthos communities, we used co-inertia analysis (COIA) (Dolédec and Chessel, 1994). This allows the simultaneous ordination of two data matrices sharing the same set of rows. It calculates co-inertia axes maximizing the covariance of the factorial scores generated in the separate ordinations of the two input tables. In this study, a normed principal components analysis (PCA) of the environmental variables and a correspondence analysis (CA) of the biotic data and normed PCA of both environmental variables and community metrics were used. Prior to analysis, abundance data for all three investigated communities of organisms were $\log _{10}(x+1)$ transformed to reduce strong intertaxonomic differences in densities. A Monte-Carlo permutation test was used to check the significance of the co-structure between the two data sets as revealed by COIA. All multivariate analyses were computed using the ADE-4 software (Thioulouse et al., 1997).

Alpha-Diversity of investigated communities was measured by two diversity indices: Simpson's index (Sim) as a measure of dominance (Simpson, 1949) and number of species $(\mathrm{Sp})$ as a measure of species richness. Saprobity index (Sap) was calculated according the method given by Zelinka and Marvan (1961). Values of phytoplankton and zooplankton species saprobity valences were taken from Wegl (1983) and for macrozoobenthos from Moog (2002).

Diversity indices were calculated with the aid of the BioDiversity Professional program McAleece (1997). All data were expressed as mean \pm standard error. The samples were compared statistically using unpaired $t$-tests at the $5 \%$ level of significance $(P<0.05)$. In order to measure the strength of the association among pairs of variables, the Pearson product moment correlation, with a $P<0.05$ level of significance, was used. The unpaired $t$-tests and Pearson product moment correlation were performed with the aid of the Sigma Stat program (version 2).

\section{Results}

\section{Interactions between aquatic communities and environmental factors}

The COIA revealed a strong co-structure between the environmental and biocoenotical data sets (correlation $=0.895$ along the first axis, Fig. 2). It was also highly significant (permutation test, $P<0.001$ ). The first two axes explained 65.6 and $25.3 \%$ of the total inertia. Conductivity and to a lesser extent SRP were negatively related to Factor 1 (F1) of COIA, whereas ${ }^{\circ} \mathrm{dH}$, DO concentration, $\mathrm{pH}$ and Chla concentration showed a positive relationship (Fig. 2, F11). It can be observed that EC and ${ }^{\circ} \mathrm{dH}$ are on opposite sides of the $\mathrm{F} 1$ axis and thus were inversely correlated $(r=-0.483, P=0.007)$. Analysing the well water 


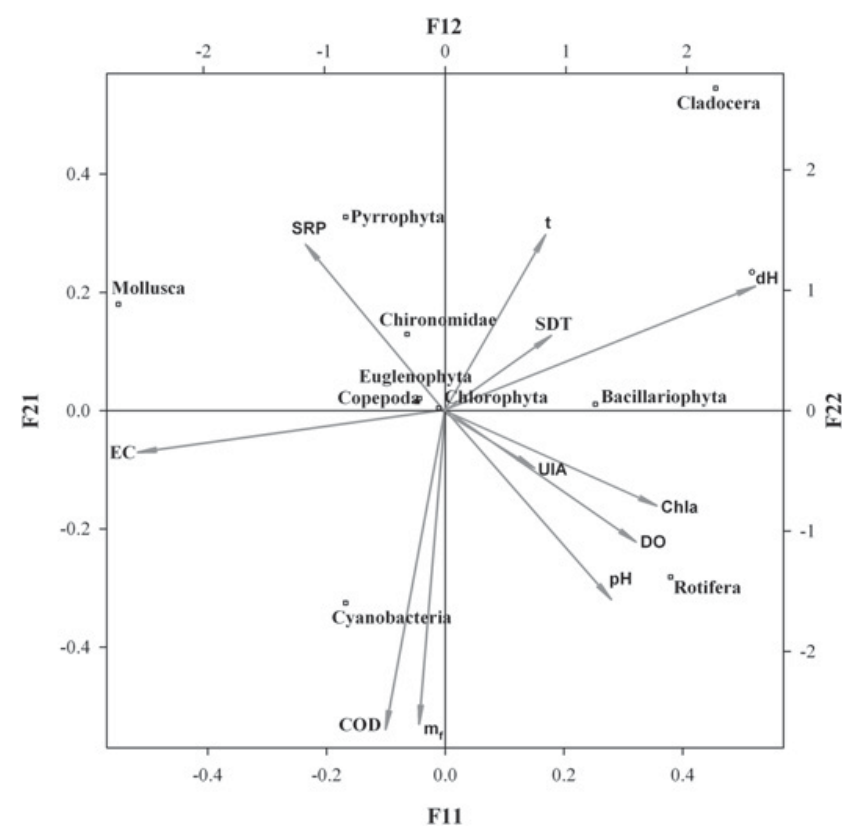

Fig. 2. Biplot presentation of the co-inertia analysis (COIA) of 11 environmental variables and taxonomic groups from 20 sampling dates. Ordination diagram of 12 normalized environmental variables $(\mathrm{mf}-$ fish biomass, $t$ - water temperature, $\mathrm{pH}$, DO - dissolved oxygen, EC - conductivity, SDT - Secchi disc transparency, SRP - soluble reactive phosphorus, UIA - unionized ammonia, ${ }^{\circ} 583 \mathrm{dH}$ - water hardness, COD - chemical oxygen demand, Chla -chlorophyll a concentration) in the COIA is represented with arrows starting from the origin and projected on the F11 $\times$ F21 factorial map. Position of taxa (white squares) is plotted onto the COIA F12 $\times$ F22 plane.

in order to determine the origin of high $\mathrm{EC}$ we found high values for sodium, $400 \mathrm{mg} . \mathrm{L}^{-1}$, chlorides, $243 \mathrm{mg} . \mathrm{L}^{-1}$ and sulphates, $194 \mathrm{mg} . \mathrm{L}^{-1}$. Calcium and magnesium were very low, $26 \mathrm{mg} . \mathrm{L}^{-1}$ and $12 \mathrm{mg} . \mathrm{L}^{-1}$, respectively.

Analysis of Table 1 shows that the values of environmental parameters from two types of water supply drastically changed between exploration years. Therefore, similar changes were observed in the case of pond water environmental parameters (Table 2). Comparison of the average values in years 2008 and 2009 (Table 2) showed that parameters negatively correlated with the F1 axis significantly increased in year 2009, whereas those positively correlated decreased in the same year.

Factor 2 (F2) was dominated in the negative region by fish biomass $\left(\mathrm{m}_{\mathrm{f}}\right)$ and COD and in the positive region by water temperature and SRP. The first three parameters characterize greater intra- than inter-seasonal variations (Fig. 3(B) for $\mathrm{m}_{\mathrm{f}}$ ) and monotonous seasonal changes (increase in the case of $\mathrm{m}_{\mathrm{f}}$, Fig. 3(B), and COD, and decrease in the case of $t$ ).

The biotic data analysis shows that the greatest interseasonal changes characterize Cladocera, Rotifera, Bacillariophyta and Mollusca (Fig. 2). First three groups are well represented in 2008 and almost completely disappear in 2009 (Table 3, Figs. 3(C) and (D)), which strongly associates them with the positive part of the F1 axis. On the contrary, the average abundance of Mollusca greatly increases in 2009 (Table 3) placing them on the negative end of the F1 axis (Fig. 2).

In addition, Rotifera and Cladocera are strongly separated along the F2 axis due to significant abundance changes during 2008. There is an abrupt drop in abundance of Cladocera, mainly Bosmina longirostris (O. F. Müller), as the absolute dominant species, after July 13, 2008 (from $1697 \pm 451$ ind. $\mathrm{L}^{-1}$ to $20 \pm 11$ ind. $\mathrm{L}^{-1}$, $P=0.002$, Fig. $3(\mathrm{C})$ ), and concomitant and equally intensive increase in abundance of Rotifera (from $1558 \pm 532$ ind. $\mathrm{L}^{-1}$ to $16404 \pm 5160$ ind. $\mathrm{L}^{-1}, P=0.010$, Fig. 3(C)) placing them at the negative and positive end of the F2 axis (Fig. 2), respectively.

Cyanobacteria, Pyrrophyta and to a lesser extent Chironomidae show a strong association with the F2 axis (Fig. 2). Analysis of their abundance dynamics shows that although pronounced, decrease in abundance in 2009 compared with 2008 is not statistically significant, due to even greater abundance variation in 2008 (Table 3, Figs. 3(A) and (D)). Up to July 28, 2008 Cyanobacteria are completely absent, while from that date, further on, they replace Chlorophyta as the dominant group of phytoplankton, and their massive appearance causes a water bloom placing them at the negative end of the F2 axis (Fig. 2). This is quite the reverse compared to Cladocera, which results in strong negative correlation between those groups $(r=-0.728, P=0.003)$. Similar negative correlation Cladocera shows with Bacillariophyta, but only in $2008(r=-0.888, P<0.001)$.

Pyrrophyta are the least abundant group of phytoplankton (Table 3), with highly variable numbers in both seasons, characterized by two maxima, the bigger one in June and smaller in September, and complete absence in July and first half of August (Fig. 3(D)), which situates them at the positive end of the F2 axis (Fig. 2).

Chironomidae abundance dynamics follows a similar pattern in both seasons with Chironomus sp. Meigen being the absolute dominant species. They decrease towards the end of the season but not monotonously, due to an additional smaller maximum in July (Fig. 3(A)). This is the opposite trend to that of fish biomass resulting in statistically significant negative correlation between them $(r=-0.528, P=0.017)$.

Table 1. Comparison between values of environmental parameters (mean \pm standard error) in surface water supply (2008) and tube well water supply (2009). Statistically significant differences $(P<0.05)$ between water sources are denoted by an asterisk.

\begin{tabular}{|c|c|c|c|c|c|c|c|}
\hline Environmental parameters & $t\left({ }^{\circ} \mathrm{C}\right)$ & $\mathrm{pH}$ & DO (mg. $\left.\mathrm{L}^{-1}\right)$ & $\mathrm{EC}\left(\mu \mathrm{S} . \mathrm{cm}^{-1}\right)$ & SRP (mg.L $\left.\mathrm{L}^{-1}\right)$ & UIA (mg.L $\left.\mathrm{L}^{-1}\right)$ & ${ }^{\circ} \mathrm{dH}$ \\
\hline Surface water supply & $20.0 \pm 1.1$ & $7.93 \pm 0.05$ & $8.79 \pm 0.86$ & $1102 \pm 24$ & $0.05 \pm 0.03$ & $0.3 \pm 0.03$ & $24.0 \pm 1.2$ \\
\hline Tube well water supply & $22.2 \pm 1.0$ & $8.82 \pm 0.03 *$ & $3.45 \pm 0.30 *$ & $2200 \pm 16^{*}$ & $0.27 \pm 0.05^{*}$ & $0.67 \pm 0.052^{*}$ & $2.12 \pm 0.41 *$ \\
\hline
\end{tabular}


Table 2. Comparison between values of lake water environmental parameters (mean \pm standard error) in two studied seasons. Statistically significant differences $(P<0.05)$ between seasons are denoted by an asterisk.

\begin{tabular}{lcc}
\hline Environmental & & \\
parameters & 2008 & 2009 \\
\hline$t\left({ }^{\circ} \mathrm{C}\right)$ & $24.1 \pm 0.8$ & $23.1 \pm 0.6$ \\
$\mathrm{pH}$ & $9.6 \pm 0.12$ & $8.9 \pm 0.02^{*}$ \\
$\mathrm{DO}\left(\mathrm{mg} . \mathrm{L}^{-1}\right)$ & $10.28 \pm 0.74$ & $3.83 \pm 0.28^{*}$ \\
$\mathrm{EC}\left(\mu \mathrm{S} . \mathrm{cm}^{-1}\right)$ & $1010 \pm 22$ & $2058 \pm 18^{*}$ \\
$\mathrm{SDT}(\mathrm{m})$ & $0.147 \pm 0.004$ & $0.140 \pm 0.007$ \\
$\mathrm{SRP}\left(\mathrm{mg} . \mathrm{L}^{-1}\right)$ & $0.07 \pm 0.04$ & $0.22 \pm 0.02^{*}$ \\
$\mathrm{UIA}\left(\mathrm{mg} . \mathrm{L}^{-1}\right)$ & $0.103 \pm 0.017$ & $0.075 \pm 0.010$ \\
${ }^{\circ} \mathrm{dH}$ & $21.75 \pm 0.73$ & $5.29 \pm 0.75^{*}$ \\
$\mathrm{COD}\left(\mathrm{mg} . \mathrm{L}^{-1}\right)$ & $74 \pm 7$ & $74 \pm 2$ \\
Chla $\left(\mu \mathrm{g} . \mathrm{L}^{-1}\right)$ & $566 \pm 47$ & $190 \pm 28^{*}$ \\
$\mathrm{~m}_{\mathrm{f}}(\mathrm{g})$ & $437 \pm 42$ & $375 \pm 35$ \\
\hline
\end{tabular}

Position near the centre of the $\mathrm{F} 1 \times \mathrm{F} 2$ factorial plane (Fig. 2) implies that changes in abundance of Euglenophyta, Chlorophyta and Copepoda both within and between the seasons are smaller compared with the above-mentioned taxonomic groups (Table 3, Figs. 3(C) and (D)). Although smaller in relative terms compared with Cladocera, Rotifera and Bacillariophyta, abundance decrease in 2009 for all three of them are highly significant (Table 3). In addition, Chlorophyta is characterized by a significant variation in abundance in 2008 (Fig. 3(D)). However, unlike Cladocera and Cyanobacteria, Chlorophyta reaches maximum abundance in the middle of 2008 season, representing the absolutely dominant phytoplankton group, placing them at the centre of the F2 axis (Fig. 2).

Analysis of Figure 3 also shows that maxima in abundance of Chironomidae in 2008 and to a lesser extent in 2009 parallel the minima in number of both plankton communities. Indeed, in 2008 the total number of phytoplankton and zooplankton show negative correlation with abundance of Chironomidae $(r=-0.666, P=0.035$, and $r=-0.675, P=0.032$, respectively).

\section{Community metrics and environmental data}

The co-structure between the environmental data and community metrics revealed by COIA (Fig. 4) was both strong, with correlation coefficient of 0.92 along the F1 axis, and highly significant, as confirmed by a MonteCarlo permutation test $(P<0.001)$. The common structure was almost unidimensional $(76.7 \%$ of the co-inertia was described along the first axis F1 and only $18.9 \%$ along the second axis F2). Environmental factors at F1 $\times$ F2 plane in Fig. 4 are almost identically placed as shown in Fig. 2, differing only in smaller significance of COD, and a few degrees counter clockwise shift of all environmental vectors, with no significant change in their interpretation.

Analysis of the community structure shows that all macrozoobenthos community metrics are highly correlated with the F2 - fish biomass axis, with both components of diversity $\left(\mathrm{sp}_{\mathrm{zb}}, \mathrm{Sim}_{\mathrm{zb}}\right)$, total abundance $\left(\mathrm{ab}_{\mathrm{zb}}\right)$ and biomass $\left(\mathrm{bm}_{\mathrm{zb}}\right)$ decreasing with increase of fish biomass $\left(\mathrm{m}_{\mathrm{f}}\right)$, whereas saprobity index $\left(\operatorname{Sap}_{\mathrm{zb}}\right)$ shows opposite trend (Fig. 4). As a result, all macrozoobenthos community metrics are statistically significantly correlated with $\mathrm{mf}, \mathrm{sp}_{\mathrm{zb}}, \mathrm{ab}_{\mathrm{zb}}$ and $\mathrm{bm}_{\mathrm{zb}}$, negatively and $\mathrm{Sim}_{\mathrm{zb}}$ and $\mathrm{Sap}_{\mathrm{zb}}$ positively and there are no statistically significant differences in these parameters between two investigation seasons. Quite the opposite situation is with plankton communities whose total abundances $\left(a b_{z p}\right.$ and $\left.a b_{f p}\right)$ significantly decrease in 2009 (Table 4) due to complex and very intensive changes in water chemistry between the years, and thus strongly associated with positive end of the F1 axis. However, response of other community metrics differs between zooplankton and phytoplankton. Although phytoplankton biomass $\left(\mathrm{bm}_{\mathrm{fp}}\right)$ is also tightly associated with the $\mathrm{F} 1$ axis, zooplankton biomass $\left(\mathrm{bm}_{\mathrm{zp}}\right)$ is more strongly associated with the F2 axis. Decrease in $\mathrm{bm}_{\mathrm{zp}}$ although highly significant (Table 4) is much lower compared with other zooplankton community metrics. In addition, bm $_{\mathrm{zp}}$ decreases along both seasons, and as a result there is a strong negative correlation between $\mathrm{m}_{\mathrm{f}}$ and $b_{\mathrm{zp}}$ in 2008 and $2009(r=-0.833, P=0.003$ and $r=-0.898, P<0.001$, respectively). On the other hand, diversity of zooplankton is strongly associated with the F1 axis and decreases dramatically in 2009 (Table 4) in species richness $\left(\mathrm{sp}_{\mathrm{zp}}\right)$, whereas it increases in equitability $\left(\operatorname{Sim}_{\mathrm{zp}}\right)$, while these diversity parameters, $\mathrm{sp}_{\mathrm{fp}}$ and $\mathrm{Sim}_{\mathrm{fp}}$, show no seasonal differences in the case of phytoplankton community (Table 4), placing them in close association with F2 axis (Fig. 4).

\section{Discussion}

This study indicates the important changes that occurred in investigated aquatic groups, especially in zooplankton, as well as in the environmental variables after the introduction of groundwater as a supply for small aquaculture ponds. The data reveal that all three groups, phytoplankton, zooplankton and macrozoobenthos responded to these changes in a relatively short time, less than 1 year, as abundance, species richness and biomass severely decreased. Initially, the investigated ponds were eutrophic having a typical fauna dominated by small bodied cladocerans, rotifers, cyclopoid copepods, chironomids and different phytoplankton species (Mayer et al., 1997; Potužak et al., 2007). The water from the tube well was characterized by low oxygen, low ${ }^{\circ} \mathrm{dH}$, high UIA and very high EC (Table 1). Although the results did not provide direct proves for the prevailing effect of either of the above-mentioned variables on the investigated communities, indirect evidence show that common eutrophic conditions present in fish ponds can sustain low oxygen and rather high UIA provided mostly by degradation of uneaten feed and fish excretion (Pechar, 2000). High EC and low ${ }^{\circ} \mathrm{dH}$ are more likely to act as the main stressors to investigated aquatic communities in this study. The reverse relation between these two parameters shows that 

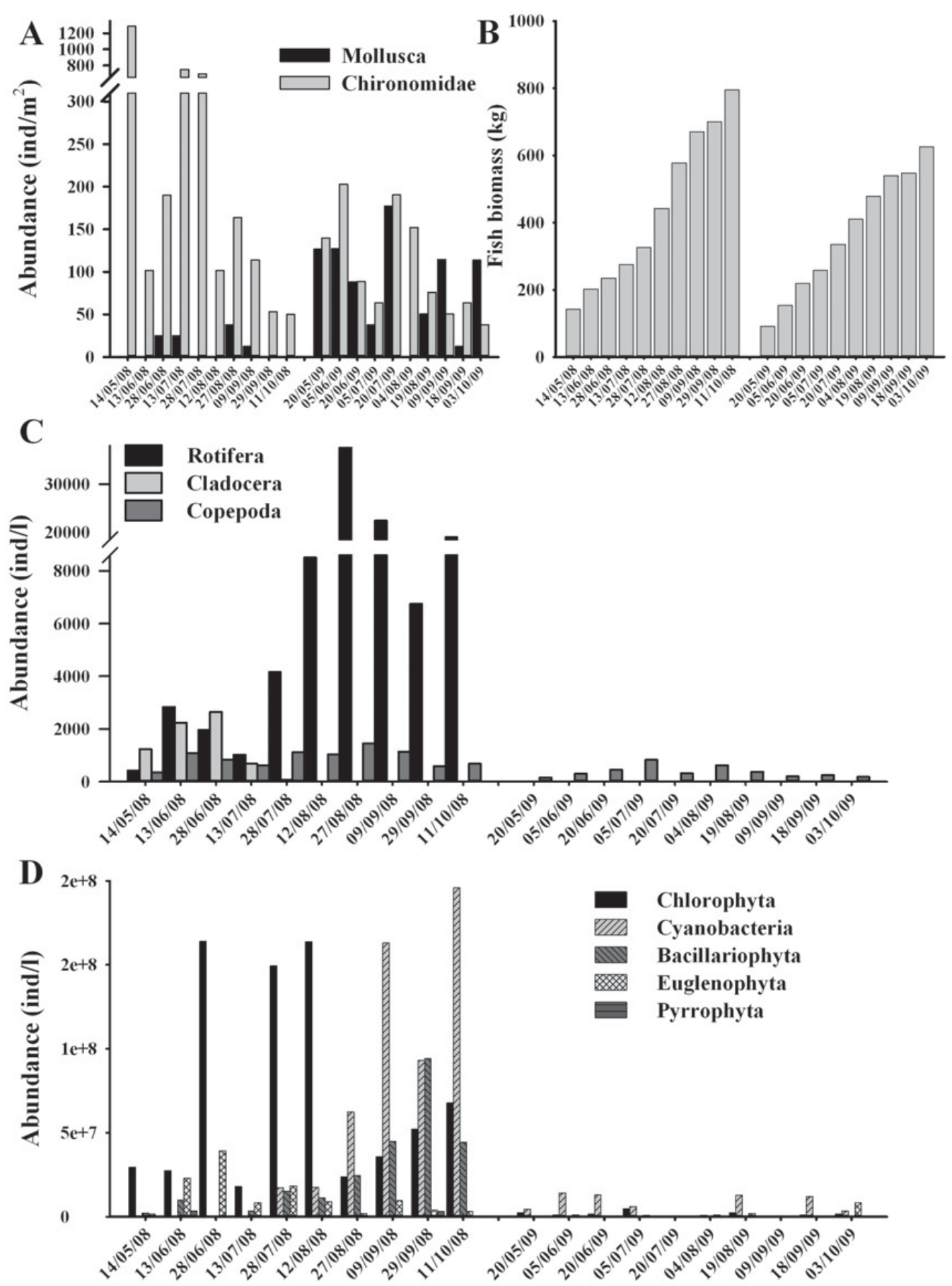

Sampling dates

Fig. 3. Changes in abundance of major taxonomic groups belonging to macrozoobentos (A), fish biomass (B), zooplankton (C) and phytoplankton (D) during the study period.

high EC did not originate from the concentrations of calcium and magnesium ions as major ions defining ${ }^{\circ} \mathrm{dH}$ (Stewart, 2001), but are the result of prevailing concentrations of sodium, chlorides and sulphate ions. However, since EC per se depends on the concentration of all ions in water, high sodium and chloride ions in the studied ponds indicate secondary salinization. Conductivity above 2000 $\mu \mathrm{S} . \mathrm{cm}^{-1}$ in the investigated ponds classifies them as subsaline (Hammer et al., 1983). Salinity is one of the very important environmental factors affecting aquatic organisms. Some authors suggest that in brackish and other transitional waters species richness is lower than in freshwater and marine habitats (Remane, 1934). Previously published data show that freshwater zooplankton species, mostly rotifers and cladocerans, show low tolerance to increasing salinity (Hart et al., 1991; 
Table 3. Comparison between abundance of investigated groups (mean \pm standard error) in two studied seasons. Statistically significant differences $(P<0.05)$ between seasons are denoted by an asterisk.

\begin{tabular}{|c|c|c|}
\hline Taxonomic groups & 2008 & 2009 \\
\hline Bacillariophyta $\left(10^{6}\right.$ ind. $\left.\mathrm{L}^{-1}\right)$ & $25.1 \pm 9.2$ & $0.07 \pm 0.03^{*}$ \\
\hline Chlorophyta (ind. $\mathrm{L}^{-1}$ ) & $73.2 \pm 19.3$ & $1.63 \pm 0.43^{*}$ \\
\hline Cyanobacteria $\left(10^{6}\right.$ ind. $\left.\mathrm{L}^{-1}\right)$ & $54.9 \pm 23.1$ & $6.78 \pm 1.8$ \\
\hline Euglenophyta $\left(10^{6}\right.$ ind.L $\left.\mathrm{L}^{-1}\right)$ & $11.8 \pm 3.8$ & $1.53 \pm 0.77 *$ \\
\hline Pyrrophyta $\left(10^{6}\right.$ ind. $\left.\mathrm{L}^{-1}\right)$ & $0.72 \pm 0.43$ & $0.09 \pm 0.04$ \\
\hline Rotatoria (ind. $\mathrm{L}^{-1}$ ) & $10466 \pm 3846$ & $14.4 \pm 3.4 *$ \\
\hline Cladocera (ind. $\mathrm{L}^{-1}$ ) & $691 \pm 319$ & $1.7 \pm 0.7^{*}$ \\
\hline Copepoda (ind. $\mathrm{L}^{-1}$ ) & $889 \pm 105$ & $369 \pm 67 *$ \\
\hline Chironomidae (ind. $\mathrm{m}^{-2}$ ) & $376 \pm 128$ & $107 \pm 19$ \\
\hline Mollusca (ind.m ${ }^{-2}$ ) & $10 \pm 5$ & $85 \pm 18 *$ \\
\hline
\end{tabular}

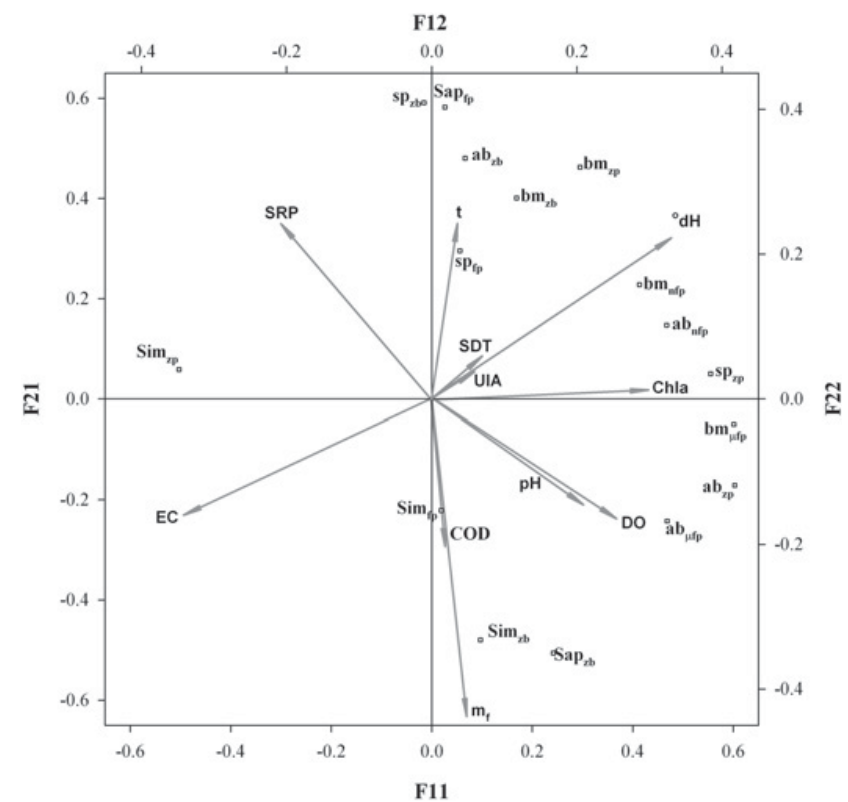

Fig. 4. Biplot presentation of the co-inertia analysis (COIA) of 12 environmental variables and 14 community metrics from 20 sampling dates. Ordination diagram of 12 normalized environmental variables (see Fig. 2 for codes) in the COIA is represented with arrows starting from the origin and projected on the F11 $\times$ F21 factorial map. Position of community metrics (white squares) is plotted onto the COIA F12 $\times$ F22 plane. Codes of the community metrics are: Sim - Simpson's index, Sp species richness, ab - total abundance, Sap - saprobity index, bm - biomass, with group of organisms that corresponding metrics describes defined in index as follows: php - phytoplankton, zp zooplankton and $\mathrm{zb}-$ macrozoobenthos.

Boronat et al., 2001; Nielsen et al., 2003, 2012; North and Houde, 2003; Waterkeyn et al., 2011).

Water temperature, COD, UIA and SDT were not significantly different between years indicating that the years were climatically similar and that the organic load in ponds was rather constant. The rest of the measured parameters ( $\mathrm{pH}$, SRP and Chla) that were significantly different in the second season had values that did not reach the threshold to be considered unusual for eutrophic conditions and thus we do not assume they affected the studied aquatic biota.

Looking at a snapshot of the bioceonosis during the two investigation years a conspicuous decrease in the abundance of all three groups, phytoplankton, zooplankton and macrozoobenthos is evident. The most significant change occurred in assemblages of Cladocera, Rotifera and Bacillariophyta that were very abundant in 2008, but almost completely disappeared in 2009 (See List of taxa and their abundances in two investigation years after References). A lot of field and experimental studies have proved that the abundance and species richness of assemblages of Rotifera and Cladocera decreases with the increase of habitat salinization (Boronat et al., 2001; Nielsen et al., 2003; Waterkeyn et al., 2011). Hart et al. (1991) showed that freshwater Cladocera are less tolerant to salinities above $1000 \mathrm{mg} . \mathrm{L}^{-1}\left(2000 \mu \mathrm{S} . \mathrm{cm}^{-1}\right)$. Furthermore, Nielsen et al. (2012) reported that average densities of the zooplankton community increased at salinities below $2500 \mathrm{mg} . \mathrm{L}^{-1}\left(4000 \mu \mathrm{S} . \mathrm{cm}^{-1}\right)$, otherwise were $<1$ ind. $\mathrm{L}^{-1}$. The common taxa at salinities above $2500 \mathrm{mg} . \mathrm{L}^{-1}$ were Cyclopoida and copepod nauplii, Lecane spp. and Lepadella spp., whereas no Cladocera were reported (Nielsen et al., 2012). Boronat et al. (2001) investigated Cladocera in a salinity gradient and reported a negative relationship between species richness and salinity. Our results are in line with the above-mentioned study, particularly concerning B. longirostris Sars G.O., the dominant Cladocera in our research. This species was absent in subsaline lakes, implying its low tolerance to habitat salinization (Boronat et al., 2001). North and Houde (2003) suggested that most of B. longirostris in their investigation were found in salinities $<1$ psu $(2000$ $\mu \mathrm{S} . \mathrm{cm}^{-1}$ ). There are also indications that at salinities above $1000 \mathrm{mg} . \mathrm{L}^{-1}\left(2000 \mu \mathrm{S} . \mathrm{cm}^{-1}\right)$, reduction in abundance and species richness in zooplankton emerging from dormant egg deposits occurs (Brock et al., 2005). The studied shallow ponds used to be agricultural land and were excavated and started fully operating as fish ponds in year 2006. We suspect that the zooplankton dormant egg bank formed during the three previous years $(2006,2007$ and 2008) contributed much less in 2009 to the zooplankton community of ponds due to increased salinity (Bailey et al., 2004). There are different scenarios that can happen to the dormant eggs bank due to unfavourable habitat conditions, from degradation and loss of viability of eggs over time (Gyllström and Hansson, 2004) to low survivorship of hatchlings (Nielsen et al., 2003). Additionally, it is still unknown how agrotechnical practices like disking, applied to dried fish ponds during winter prior to filling with water in spring, affect the zooplankton egg bank. Disking is a measure that vertically mixes soil as deep as $10 \mathrm{~cm}$, bringing the lower layers of soil to the surface. In the case of studied ponds, this practice was applied between two investigation years. However, even if this activity brought the dormant eggs to the surface layers of the pond bottom, apparently they did not hatch due to increased EC. The fate of dormant eggs is still unknown regarding bioturbation from wave action 
Table 4. Comparison between community metrics of investigated communities (mean \pm standard error) in two studied seasons. Statistically significant differences $(P<0.05)$ between seasons are denoted by an asterisk.

\begin{tabular}{|c|c|c|c|c|c|c|}
\hline & \multicolumn{2}{|c|}{ Phytoplankton } & \multicolumn{2}{|c|}{ Zooplankton } & \multicolumn{2}{|c|}{ Macrozoobenthos } \\
\hline & 2008 & 2009 & 2008 & 2009 & 2008 & 2009 \\
\hline Abundance (ind. $\left.\mathrm{L}^{-1}\right)^{\mathrm{a}}\left(\text { ind. } \mathrm{m}^{-2}\right)^{\mathrm{b}}$ & $166 \pm 31 \times 10^{6 a}$ & $10 \pm 2 \times 10^{6 * a}$ & $12046 \pm 3756^{\mathrm{a}}$ & $385 \pm 65^{* a}$ & $394 \pm 129^{b}$ & $197 \pm 33^{b}$ \\
\hline Biomass $\left(m g . L^{-1}\right)^{a}\left(g \cdot m^{-2}\right)^{b}$ & $172 \pm 6^{\mathrm{a}}$ & $32 \pm 1^{* a}$ & $4.39 \pm 0.12^{\mathrm{a}}$ & $3.86 \pm 0.07 * \mathrm{a}$ & $3.11 \pm 0.78^{b}$ & $1.54 \pm 0.17^{b}$ \\
\hline Simpson's index & $0.38 \pm 0.03$ & $0.39 \pm 0.05$ & $0.35 \pm 0.03$ & $0.62 \pm 0.03^{*}$ & $0.71 \pm 0.07$ & $0.69 \pm 0.05$ \\
\hline Spec & $17.6 \pm 1.1$ & $16.5 \pm 1.3$ & $10.9 \pm 0.6$ & $3.5 \pm 0.3^{*}$ & $2.4 \pm 0.5$ & $2.0 \pm 0.3$ \\
\hline Saprobity index & $1.93 \pm 0.04$ & $1.86 \pm 0.04$ & - & - & $2.60 \pm 0.15$ & $2.45 \pm 0.08$ \\
\hline
\end{tabular}

${ }^{\mathrm{a}}$ Units for phytoplankton and zooplankton.

${ }^{\mathrm{b}}$ Units for macrozoobenthos.

and/or burrowing activities of benthic fish (e.g., common carp) and chironomid and oligochaeta larvae (Gyllström and Hansson, 2004) present in carp ponds.

Similarly to Cladocera, high EC can affect Rotifera and their dormant eggs (Chittapun et al., 2005). Green (1993) suggests that the number of Rotifera can decline at EC even below $1000 \mu \mathrm{S} . \mathrm{cm}^{-1}$, whereas they are reduced to a few species at values over $3000 \mu \mathrm{S} . \mathrm{cm}^{-1}$.

Bacillariophyta was rather low in species diversity in the first investigation year, but some species as the cosmopolitan Nitzschia acicularis (Kutzing) W. Smith, were very abundant. Similar diversity but a significant drop in species density was observed in the next year (Fig. 3(D); List of taxa and their abundances in two investigation years, see online material). Bacillariophyta are good indicators of changes in salinity and ionic composition in aquatic habitats (Fritz et al., 1999). Blinn and Bailey (2001) observed diatoms in streams with a range of salinities, from 43 to $14100 \mu \mathrm{S} . \mathrm{cm}^{-1}$, and found lower diatom species richness and diversity in water bodies located in areas with high secondary salinization, especially regions with heavy irrigation practices. The area where the investigated ponds are located is surrounded by intensively maintained agricultural land with orchards and vineyards thus were probably affected additionally by runoff from nearby land.

Differing from the rest of studied groups, Mollusca were the most successful group in the second year, since their number greatly increased (Fig. 3(A); List of taxa and their abundances in two investigation years, see online material). This could not be simply explained by the change in water chemistry, since lower ${ }^{\circ} \mathrm{dH}$ and $\mathrm{pH}$ in 2009 are not favourable for most Mollusca. However, two cosmopolitan species, Planorbarius corneus Linnaeus and Gyraulus sp. Charpentier were present in the studied ponds (Wesselingh et al., 1999). One of their preferences is that they can survive in temporary ponds (JurkiewiczKarnkowska, 2008) and additionally are tolerant to low oxygen conditions (Glöer and Meier-Brook, 2003) and a range of salinities (Hynes, 1966). Thus, their increase in the second years can lead to a conclusion that these species have a strategy of gradually inhabiting a new space.

Chironomidae demonstrated a well-known general pattern present in fish ponds, i.e. decreasing abundance towards the end of the season (Fig. 3(A); List of taxa and their abundances in two investigation years, see online material), being in line with the increasing fish biomass (Fig. 3(B)) conforming the consistent predator-prey link between these groups (Adámek et al., 2003; Rahman et al., 2010).

Within seasons, especially during 2008, changes in the communities of zooplankton and phytoplankton were observed. A shift in zooplankton community between Cladocera and Rotifera occurred in the first investigation year (Fig. 3(C)). B. longirostris, the dominant cladoceran species, almost entirely vanish after mid-July providing space for flourishment of Rotifers through lessening the competition for food between these two (Yang et al., 2005). One of the reasons for the crash of Bosmina population could be explained by the predatory pressure from fish, since high water temperature (Rettig et al., 2006) and eutrophic state are factors favouring the development of this species (Kuczyńska-Kippen and Joniak, 2010). Although there is some controversy going on concerning the size of common carp preferring zooplankton in their diet (Rahman et al., 2010) there is evidence that carp can consume smaller crustaceans, especially when they are in very high densities (Milstein, 1992). Additionally, the disappearance of Cladocera coincided with the appearance of Cyanobacteria (Fig. 3(D)) leading to the conclusion that blue-green algae might have been suppressed by the dominant $B$. longirostris. The general opinion is that the Cyanobacteria are uneatable for cladocerans; however, there are investigations indicating that Bosmina sp. can consume them. In the Lake Terra Nova a high increase in Bosmina coincided with a significant reduction in Cyanobacteria implying that this small cladoceran can feed on filamentous blue-green bacteria (Ter Heerdt and Hootsmans, 2007). A similar event happened in Lake Vogelengzang where Cyanobacteria disappeared after Bosmina peaked in abundance (Van Der Vlugt et al., 1992). Another major shift between Chlorophyta and Cyanobacteria occurred in mid-August 2008 (Fig. 3(D)). This change in the phytoplankton community was probably a consequence of a fourfold increase of rotifers (Fig. 3(C)). By depleting "edible" algae (mostly Chlorophyta in our study), rotifers emptied an ecological niche thus providing space for the development of Cyanobacteria. Additionally, the environmental conditions in mid August favoured blue-green algae, as high water temperatures high organic and no vertical mixing (Reynolds, 2006) common in midsummer in 
eutrophic man-made ponds. A gradual decrease of rotifers in the next two sampling occasions concurred with gradual increase in Chlorophyta abundance until the end of the season.

The groups that had the least difference in abundance during and in-between investigation years were Euglenophyta, Chlorophyta and Copepoda (Cyclopoida). Copepoda were mostly characterized by a change in the prevailing life stages between seasons, with larval stages dominating during 2008 season (on average 68\%), and adults in the next season (on average 76\%). However, even though density of Cyclopoid copepods was significantly lower in the second season $(P<0.001)$, it was still rather high compared with poorly developed Rotifera and Cladocera (Table 3). Therefore, it can be presumed that this group of zooplankton is much less susceptible to changes in water chemistry, specially the adults, since prevailing in 2009, and are moreover, better in colonizing new habitats (Jenkins and Buikema, 1998; Cáceres and Soluk, 2002).

Fish reared in the studied ponds seemed to be unaffected by changed water chemistry, since variations in biomass throughout the seasons were similar (Fig. 3(B)). Common carp is known for its high tolerance to a wide range of environmental conditions (Horvath et al., 2002).

However, we must say that the investigated communities of phytoplankton, zooplankton and macrozoobenthos in the second year did not have the same starting position since a part of the aquatic biota present in the first year were passively introduced by the water supply coming from a variety of surface waters. On the other hand, high dispersal capacity and colonization potential of zooplankton assemblages, the group that experienced the most dramatic change, particularly when source habitats are nearby (De Meester et al., 2002; Louette and De Meester, 2005) (the reservoir pond, open wells and a small stream), imply higher rate of population establishment than was observed in our study. Louette and De Meester (2005) reported that limiting local environmental factors should be considered when concluding on the establishment success of highly dispersible zooplankton organisms. Thus, we believe that, especially in the case of zooplankton, this unevenness in the initial populations in ponds was not the cause of the significant decrease in species richness, abundance and biomass.

The community metrics confirmed some of the obtained results. Overall macrozoobenthos metrics depended on fish biomass, whereas plankton metrics were mostly affected by changed environmental conditions. As expected Sap of macrozoobenthos showed positive association with fish biomass since both communities can contribute to the bioturbation effect (Biswas et al., 2009). Further on, the diversity of zooplankton (species richness and equitability) were also inevitably under the influence of changed water chemistry since 29 out of 44 species disappeared, implying that there was no regionally available stress-tolerant taxa that could replace the existing ones (Thompson and Shurin, 2012). Probably due to the high presence of Cyclops sp. adults in 2009, zooplankton biomass decreased considerably less compared with abundance.

Differences in diversity are much smaller in the case of phytoplankton community. Nevertheless, this does not imply that the change in environmental parameters had no influence on the qualitative composition of phytoplankton community, since 49 out of 126 species disappeared in 2009. However, unlike zooplankton community where the lost of taxa were not replaced with new ones, phytoplankton community in 2009 was enriched with 35 new taxa.

Currently the diversity of aquatic communities of small lakes and ponds, natural and man-made, are under strong anthropogenic influence. Overall, the response of all three studied aquatic communities to new environmental conditions provided by groundwater supply evidently deteriorated by secondary salinization, can provide insight into a possible scenario happening to freshwater biota in small lakes and ponds and serve as a reference in ecological monitoring of small standing water bodies.

Acknowledgements. This study was supported by the project TR 31075 funded by the Ministry of Education and Science, Republic of Serbia. We are grateful to all the members of the project team. Special thanks to our PhD student Katarina Bjelanović for help in macrozoobenthos identification.

\section{References}

Abrantes N., Nogueira A. and Goncalves F., 2009. Short-term dynamics of cladocerans in a eutrophic shallow lake during a shift in the phytoplankton dominance. Ann. Limnol. - Int. J. Lim., 45, 237-245.

Adámek Z., Sukop I., Rendón P.M. and Kouřil J., 2003. Food competition between $2+$ tench (Tinca tinca L.), common carp (Cyprinus carpio L.) and bigmouth buffalo (Ictiobus cyprinellus Val.) in pond polyculture. J. Appl. Ichthyol., 19, $165-169$.

Alabaster J.S. and Lloyd R., 1980. Water Quality Criteria for Freshwater Fish, Butter-Worths, London, 297 p.

APHA 1998. Standard Methods for the Examination of Water and Wastewater, American Public Health Association, Washington, DC.

Bailey S.A., Duggan I.C., Van Overdijk C.D.A., Johengen T.H., Reid D.F. and Macisaac H.J., 2004. Salinity tolerance of diapausing eggs of freshwater zooplankton. Freshwat. Biol., 49, 286-295.

Biswas J.K., Rana S., Bhakta J.N. and Jana B.B., 2009. Bioturbation potential of Chironomid larvae for the sediment-water phosphorus exchange in simulated pond systems of varied nutrient enrichment. Ecol. Eng., 35, 1444-1453.

Blinn D.W. and Bailey P.C.E., 2001. Land-use influence on stream water quality and diatom communities in Victoria, Australia: a response to secondary salinization. Hydrobiologia, 466, 231-244.

Boronat L., Miracle M.R. and Armengol X., 2001. Cladoceran assemblages in a mineralization gradient. Hydrobiologia, 442, 75-88. 
Brock M.A., Nielsen D.L. and Crossie K., 2005. Changes in biotic communities developing from freshwater wetland sediments under experimental salinity and water regimes. Freshwat. Biol., 50, 1376-1390.

Cáceres C. and Soluk D., 2002. Blowing in the wind: a field test of overland dispersal and colonization by aquatic invertebrates. Oecologia, 131, 402-408.

Céréghino R., Ruggiero A., Marty P. and Angélibert S., 2008. Biodiversity and distribution patterns of freshwater invertebrates in farm ponds of a south-western French agricultural landscape. Hydrobiologia, 597, 43-51.

Chittapun S., Pholpunthin P. and Segers H., 2005. Restoration of tropical peat swamp rotifer communities after perturbation: an experimental study of recovery of rotifers from the resting egg bank. Hydrobiologia, 546, 281-289.

Cho W.-S., Park Y.-S., Park H.-K., Kong H.Y. and Chon T.-S., 2011. Ecological informatics approach to screening of integrity metrics based on benthic macroinvertebrates in streams. Ann. Limnol. - Int. J. Lim., 47, 51-62.

De Meester L., Gomez A., Okamura B. and Schwenk K., 2002. The monopolization hypothesis and the dispersal-gene flow paradox in aquatic organisms. Acta Oecol., 23, 121-135.

Dolédec S. and Chessel D., 1994. Co-inertia analysis: an alternative method for studying species-environment relationships. Freshwat. Biol., 31, 277-294.

Flosner D., 1972. Krebstiere, Crustacea, Kiemen und Blattfußer, Branchiopoda, Fischlause, Branchiura. Die tierwelt deutschlands, VEB Gustav Fischer Verlag, Jena, 501 p.

Fritz S.C., Cumming B.F., Gasse F. and Laird K.R., 1999. Diatoms as indicators of hydrologic and climatic changes in saline lakes. In: Stoermer E.F. and Smol J.P. (eds.), The Diatoms: Applications for the Environmental and Earth Sciences, Cambridge University Press, UK, 41-72.

Glöer P. and Meier-Brook C., 2003. Süswassermollusken, Deutscher Jugenbund für Naturbeoachung, Hamburg, $134 \mathrm{p}$.

Green J., 1993. Zooplankton associations in East African lakes spanning a wide salinity range. Hydrobiologia, 267, 249-256.

Gyllström M. and Hansson L.A., 2004. Dormancy in freshwater zooplankton: induction, termination and the importance of benthic-pelagic coupling. Aquat. Sci., 66, 274-295.

Hammer U.T., Shamess J. and Haynes R., 1983. The distribution and abundance of algae in saline lakes of Saskatchewan, Canada. Hydrobiologia, 105, 1-26.

Hart B.T., Bailey P., Edwards R., Hortle K., James K., McMahon A., Meredith C. and Swadling K., 1991. A review of the salt sensitivity of the Australian freshwater biota. Hydrobiologia, 210, 105-144.

Hillebrand H., Dürselen C.D., Kirschtel D., Pollingher U. and Zohary T., 1999. Biovolume calculation for pelagic and bentic microalgae. J. Phycol., 35, 403-424.

Horvath L., Tamas G. and Seagrave C., 2002. Carp and Pond Fish Culture, Blackwell Science, Oxford, 169 p.

Huber-Pestalozzi G., Komarek J. and Fott B., 1983. Phytoplankton des süßwasser. Chlorophyceae, ordnung: Chlorococcales, E. Schweizerbartsche Verlagsbuchhandung, Stuttgart, $1044 \mathrm{p}$.

Hull A., 1997. The pond life project: a model for conservation and sustainability. In: Boothby J. (ed.), British Pond Landscape. Proceedings from the UK Conference of the Pond Life Project, Liverpool, 101-109.
Hynes H.B.N., 1966. The Biology of Polluted Water, Liverpool University Press, Liverpool, 202 p.

Jeffries M.J., 2002. Evidence for individualistic species assembly creating convergent predator: prey ratios among pond invertebrate communities. J. Anim. Ecol., 71, 173-184.

Jenkins D.G. and Buikema A.L., 1998. Do similar communities develop in similar sites? A test with zooplankton structure and function. Ecol. Monogr., 68, 421-443.

Jurkiewicz-Karnkowska E., 2008. Aquatic mollusk communities in riparian sites of different size, hydrological connectivity and succession stage. Pol. J. Ecol., 56, 99-118.

Komárek J. and Anagnostidis K., 1998. Süßwasserflora von mitteleuropa. Cyanoprokaryota. Chroococcales, Spektrum Akademischer Verlag, Heidelberg, Berlin, 548 p.

Komárek J. and Anagnostidis K., 2005. Süßwasserflora von mitteleuropa, Cyanoprokaryota. Oscillatoriales, Spektrum Akademischer Verlag, Heidelberg, Berlin, 759 p.

Koste W., 1978. Rotatoria. Die Radertiere Mitteleuropas, Überorderung Monogononta, Gerbruder Brontraeger, Berlin, $673 \mathrm{p}$.

Krammer J. and Lange-Bertalot H., 1986. Süßwasserflora von mitteleuropa. Bacillariophyceae. Naviculaceae, Gustav Fischer Verlag, Stuttgart, 876 p.

Krammer J. and Lange-Bertalot H., 1988. Süßwasserflora von mitteleuropa. Bacillariophyceae. Bacillariaceae, Epithemiaceae, Surirellaceae, Gustav Fischer Verlag, Stuttgart, 596 p.

Kuczyńska-Kippen N. and Joniak T., 2010. The impact of water chemistry on zooplankton occurrence in two types (field versus forest) of small water bodies. Int. Rev. Hydrobiol., 95, 130-141.

Louette G. and De Meester L., 2005. High dispersal capacity of cladoceran zooplankton in newly founded communities. Ecology, 86, 353-359.

Mayer J., Dokulil M.T., Salbrechter B.M., Posch T., Pfister G., Kirschner A.K.T., Velimirov B., Steitz A. and Ulbricht T., 1997. Seasonal successions and trophic relations between phytoplankton, zooplankton, ciliate and bacteria in a hypertrophic shallow lake in Vienna, Austria. Hydrobiologia, 342/343, 165-174.

McAleece N., 1997. Biodiversity Pro. The Natural History Museum, London.

Milstein A., 1992. Ecological aspects of fish species interactions in polyculture ponds. Hydrobiologia, 231, 177-186.

Moller Pillot H.K.M., 2009. Chironomidae Larvae of the Netherlands and Adjacent Lowlands: Biology and Ecology of the Chironomini, KNNV Publishing, Zeist, 288 p.

Moog O., 2002. Fauna Aquatica Austriaca. A comprehensive species inventory of Austrian aquatic organisms with ecological notes, Federal Ministry of Agriculture, Forestry, Environment and Water Management, Vienna.

Morduhai-Boltiviskoi B.D., 1954. Materialji po srednemu vesu vodnih bespozvonočnih dnepra. Trudi problemnih i tematičeskih sovešcanija zin. Problemy gidrobiologii vnutrennikh vod: Tr. problem. i temat. soveshch. M. Zool. in- $t$ AN SSSR. Vyp., 2, 223-241.

Nielsen D.L., Brock M.A., Crosslé K., Harris K., Healey M. and Jarosinski I., 2003. The effects of salinity on aquatic plant germination and zooplankton hatching from two wetland sediments. Freshwat. Biol., 48, 2214-2223.

Nielsen D.L., Smith D., Petrie R., 2012. Resting egg banks can facilitate recovery of zooplankton communities after 
extended exposure to saline conditions. Freshwat. Biol., 57, 1306-1314.

North E.W. and Houde E.D., 2003. Linking ETM physics, zooplankton prey, and fish early-life histories to striped bass Morone saxatilis and white perch $M$. americana recruitment. Mar. Ecol. Prog. Ser., 260, 219-236.

Pechar L., 2000. Impact of long-term changes in fishery management on the trophic level water quality in Czech fish ponds. Fisheries Manage. Ecol., 7, 23-31.

Potužak J., Huda J. and Pechar L., 2007. Changes in fish production effectivity in eutrophic fishponds - impact of zooplankton structure. Aquacult. Int., 15, 201-210.

Rahman M., Kadowaki S., Balcombe S. and Wahab M., 2010. Common carp (Cyprinus carpio L.) alters its feeding niche in response to changing food resources: direct observations in simulated ponds. Ecol. Res., 25, 303-309.

Remane A., 1934. Die brackwasserfauna. Verzeichnis der Veröffentlichungen Goldsteins, 36, 34-74.

Rettig J., Schuman L. and McCloskey J., 2006. Seasonal patterns of abundance: do zooplankton in small ponds do the same thing every spring-summer? Hydrobiologia, 556, 193-207.

Reynolds C. S., 2006. The Ecology of Phytoplankton, Cambridge University Press, Cambridge, 552 p.

Rozkošny R., 1980. Klič larev vodneho hmyzu, Ceskoslovenska Akademie Ved, Praha, Czech Republic, 521 p.

Ruggiero A., Céréghino R., Figuerola J., Marty P. and Angélibert S., 2008. Farm ponds make a contribution to the biodiversity of aquatic insects in a French agricultural landscape. C. R. Biol., 331, 298-308.

Simpson E.H., 1949. Measurement of diversity. Nature, 163, 688.

Smayda T.J., 1978. From phytoplankters to biomass. In: Sournia A. (ed.), Phytoplankton Manual. Monographs on Oceanographic Methodology 6, UNESCO, Paris, 273-279.

Stewart A.J., 2001. A simple stream monitoring technique based on measurements of semi-conservative properties of water. J. Environ. Manage., 27, 37-46.

Ter Heerdt G. and Hootsmans M., 2007. Why biomanipulation can be effective in peaty lakes. Hydrobiologia, 584, 305-316.
Thioulouse J., Chessel D., Dole'Dec S. and Olivier J.M., 1997. Ade-4: a multivariate analysis and graphical display software. Stat. Comput., 7, 75-83.

Thompson P.L. and Shurin J.B., 2012. Regional zooplankton biodiversity provides limited buffering of pond ecosystems against climate change. J. Anim. Ecol., 81, 251-259.

Vallenduuk H.J. and Moller Pillot H.K.M., 2007. Chironomidae Larvae of the Netherlands and Adjacent Lowlands: General ecology and Tanypodinae, KNNV Publishing, Zeist, 144 p.

Van Der Vlugt J.C., Walker P.A., Does J. and Raat A.J.P., 1992. Fisheries management as an additional lake restoration measure: biomanipulation scaling-up problems. Hydrobiologia, 233, 213-224.

Waterkeyn A., Vanschoenwinkel B., Vercampt H. and Grillas P., 2011. Long-term effects of salinity and disturbance regime on active and dormant crustacean communities. Limnol. Oceanogr., 56, 1008-1022.

Wegl R. 1983. Index für die Limnosaprobitat. Wass. Abwass., 26, $1-175$.

Wesselingh F.P., Cadée G.C. and Renema W., 1999. Flying high: on the airborne dispersal of aquatic organisms as illustrated by the distribution histories of the gastropod genera Tryonia and Planorbarius. Neth. J. Geosci., 78, 165-174.

Williams P., Biggs J., Corfield A., Fox G., Walker D. and Whitfield M., 1997. Designing new ponds for wildlife. $\mathrm{Br}$. Wildl., 8, 137-150.

Williams P., Whitfield M., Biggs J., Bray S., Fox G., Nicolet P. and Sear D., 2004. Comparative biodiversity of rivers, streams, ditches and ponds in an agricultural landscape in Southern England. Biol. Conserv., 115, 329-341.

Wood P.J., Greenwood M.T. and Agnew M.D., 2003. Pond biodiversity and habitat loss in the UK. Area, 35, 206-216.

Yang Y.F., Huang X.F., Liu J.K. and Jiao N.Z., 2005. Effects of fish stocking on the zooplankton community structure in a shallow lake in China. Fisheries Manage. Ecol., 12, 81-89.

Zelinka M. and Marvan P., 1961. Zur Prazisierung der biologischen Klassifikation der Reinheit flisender Gewasser. Arch. Hydrobiol., 57, 389-407. 